\title{
Therapeutic potential of snake venoms as antimicrobial agents
}

\author{
Md. Iqbal Alam ${ }^{1 *}$, Ojha R ${ }^{1}$, Alam MA'2 Quasimi $\mathrm{H}^{1}$ and Alam $\mathrm{O}^{3}$ \\ ${ }^{1}$ Department of Physiology, Hamdard Institute of Medical Sciences \& Research, Jamia Hamdard, New Delhi, India \\ ${ }^{2}$ Division of Neurosurgery, Department of Clinical Neurosciences, University of Cambridge, Biomedical Campus, Cambridge, UK \\ ${ }^{3}$ Department of Pharmaceutical Chemistry, SPER, Jamia Hamdard, New Delhi, India
}

\begin{abstract}
Therapeutic potential of toxins has stimulated great interest in the scientific community. Snake venoms are the complex mixture of bioactive agents with diverse pharmacological activities against a wide range of pathophysiological conditions. Literature abounds in naturally occurring proteins/peptides showing antimicrobial activities. Snake venoms are vast natural source of proteins/peptides that are not thoroughly explored till-date for their antimicrobial potency. Antimicrobial resistance is rapidly increasing along with the development of classical antibiotics. Consequently, there is an urgent need to develop new antimicrobials or antibacterial trial products via drug designing for treatment of multidrug-resistant microorganism infections. In order to highlight snake venoms - a promising source for an antimicrobial agent, the present article discusses the identified antibacterial components isolated or purified from venoms of different snake species. Eventually, this review also revealed that the snake venoms are not an uncharted source for antimicrobial activity. As compared to other biological activities of snake venom, the antibacterial profile of these natural sources has not yet fully delves into despite the reports of the positive result. The literature discussed in this review article will help in better understanding the usefulness of the various components of snake venom against a wide range of microbial species.
\end{abstract}

\section{Introduction}

Snakes have been a subject of fascinations, fear, and myths throughout history. In the ancient Greek world, the God of medicine was depicted with a stick entwined with a snake, the symbol that is still used to represent the guilds of medicine and pharmacy

Snake venom, though greatly feared is a natural biological resource, containing several components that could be of potential therapeutic value. Nature has been the traditional source and inspiration for drug discovery for thousands of years, among which snake venoms form a rich source of bioactive molecules [1]. In Ayurvedic medicine, snakes have been used to treat arthritis, gastrointestinal ailments and to prolonged life since the seventh century B.C [2]. Since 1930s, cobra venom has been used to treat various diseases like asthma, polio, multiple sclerosis, rheumatism, severe pain and trigeminal neuralgia [3]. It was also noted that the snake bite victims are not observed to suffer from wound infections even with the heavy colonization of pathogenic bacteria in the oral cavity of the snake. These observations lead to the theory that snake venom may contain antimicrobial activity [4]. Whilst the importance of antimicrobial components in snake venoms is yet to be fully extracted, it has been hypothesized that these components in the oral secretions of the snake have been developed under evolutionary pressure as a defense mechanism for the snake against the microorganisms present on its prey. The mechanism of toxin secretion in snakes is highly conserved and diversification of matured toxin sequences shows the existence of multiple protein isoforms in the venoms to comply within prey environment. The action of venom is the combined effect of all components present and interestingly, the snake escapes the effect of its own toxins due to specific resistance mechanism and modulation of acetylcholine receptors.
Snake venoms are complex mixtures consisting of loads of biologically active proteins/peptides representing a promising source of potential therapeutics for both humans and animals. These components are extensively studied for a wide range of pharmacological properties. However, it is quite exceptional that very little is known about the antimicrobial activity of venoms. Multidrug-resistant strains bacterial infections are one of the leading causes of death and an important health issue. There is a great urgency for new antibacterial sources and agents for controlling these multi-resistant pathogens [5]. In this review, we summarize the available literature linked to the antimicrobial activity of snake venom proteins such as L-amino acid oxidase (LAAO), phospholipase A2 (PLA2), antimicrobial peptides viz., cathelicidins, cardiotoxins, mycotoxins.

\section{Need for natural antimicrobial agent}

Healthcare-associated infections (HAIs) are causes of mortality and morbidity worldwide. Recently, inappropriate and excessive uses of natural, synthetic and chemically modified antibiotics have posed a serious threat to the human health. Apart from these obvious reasons, this drug resistance is, unfortunately, a consequence of other factors too viz., a gradual decline in the research and development of new antibiotics, and the absence of strict guidelines for their application.

*Correspondence to: M.I Alam, Department of Physiology, Hamdard Institute of Medical Sciences \& Research, Jamia Hamdard, New Delhi, India E-mail: iqbalasc@yahoo.com

Key words: alternative medicine, anti-microbial agents, Naja naja, natural proteins/peptides, PLA2, snake venom

Received: September 23, 2019; Accepted: October 09, 2019; Published: October 14,2019 
Resistance, in particular, multidrug resistance (MDR) development among microorganisms limits the useful lifespan of antibiotics and results in the requirement of a constant introduction of new compounds $[6,7]$. With health care professionals running short on ammunition in their battles against antibiotic-resistant infections, experts warn that the lack of investment in antibiotic research and development could adversely cost people their health specifically when infected by superbugs. Therefore, screening of newer and natural antimicrobial agents from microbial, plant and animal sources has been ventured throughout the world and the development of new drugs represents one of the most promising sectors of the pharmaceutical industry. New antimicrobials will always be necessary to fight against pathogenic microorganisms, in spite of reaching future positive statistics on microbial use [8]. Moreover, these drugs will be paramount, mainly for treating elderly people, children and immune-compromised patients [9-11]. With the threat of post-antibiotic era it is even more imperative to explore and find new and effective antibiotics from novel sources such as snake venom [12]

'Golden Age' of antibiotic discovery (1940-1960) beginning with penicillin, streptomycin and other major structural classes of antibiotics transformed clinical medicine, providing an effective cure for the most prevalent diseases of the time (Figure 1). Antibiotics have saved millions of lives and helped in alleviating human sufferings. Penicillinresistant Staphylococcus aureus has unfortunately evolved four years after the commercial introduction of penicillin $[13,14]$. The secreting enzyme $\beta$-lactamase by resistant strain destroys penicillin (a $\beta$-lactam antibiotic) [15]. In the late 1950s, penicillin's effect reduced to only $15 \%$ of infections caused by S. aureus. By early 1970s, these therapies seemed to be inefficient as antibiotic resistance was emerging and resulting in pursuit for new drugs with minimum side-effect and bacterial resistance. With the increasing number of clones of methicillinresistant S. aureus (MRSA), the spread of antibiotic resistance was continued $[13,15]$. Along with this line, attempts were made by research scientists, academicians and pharmaceutical companies on designing a new or far advanced antibacterial agent with a different mode of actions from $\beta$-lactams. Very soon, glycopeptide antibiotics (Vancomycin and its sister antibiotic Teicoplanin), glycosylated cyclic or polycyclic nonribosomal peptides that suppress bacterial peptidoglycan synthesis was introduced. The efficiency of the newly discovered antibiotics in fighting bacterial resistance crisis for 15 years, guaranteed the glycopeptide antibiotics being considered as the last resort of drugs in combating gram-positive bacterial infections including the multidrug-resistant superbug, MRSA [14-16]. The second generation of glycopeptide antibiotics, such as oritavancin, telavancin and dalbavancin discovered as a consequence of the subsequent effort in overcoming the continuing glycopeptide resistance incidence. These glycopeptides have enhanced antibacterial potency and efficacy as compared to vancomycin [16]. Although $\beta$-lactams and glycopeptides are still the first lines of defense, there is a critical need for extraordinary direct therapies to counter bacterial infections and the potential occurrence of antibiotic resistance.

In spite of stupendous advances in the biological sciences, the difficulty in identifying new mechanisms to kill bacterial pathogens is depressing. Thus, finding alternative sources of new drugs or prototypes is of major interest to complementary medicine. In recent times, the scientists all over the world are trying to hunt for the novel antimicrobial agents to control antibiotic-resistant bacteria. Natural products are an important source of medicinal compounds. Such bioactive compounds are reported to be produced by a wide variety of organisms and some of these natural substances have been shown to be able to kill bacteria $[17,18]$ and most of them resulted from extraction and isolation of plant, animal and microorganism toxins. As an example of one of these cases, snake venoms were also assayed in order to investigate their antimicrobial activities giving promising results. Although a variety of venom-derived drugs have been currently undergoing clinical trials or in preclinical development for treating a wide range of pathophysiological conditions, including chronic pain, diabetes, autoimmune disease, wound healing, HIV, cancer and hypertension, the full potential of venom as a source of antibacterial agent remains to be fully realized which is step by step discussed in the following paragraphs.

\section{Golden Age of Antibiotics Discovery}

Golden Age of Medicinal Chemistry

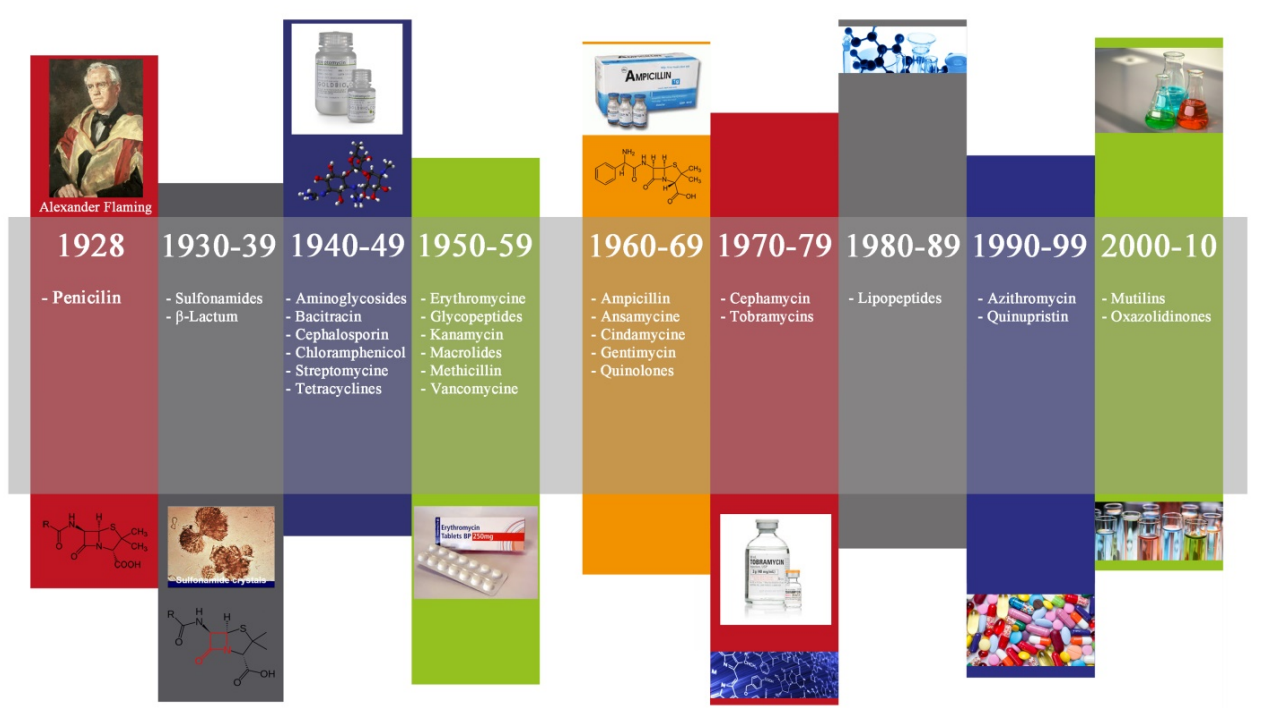

Figure 1. The above figure depicts the golden age of antibiotic discovery and golden age of medicinal chemistry. The golden age of antibiotic discovery began with the discovery of penicillin which is later succeeded by drug designing and chemical synthesis 


\section{Snake venom composition including antimicrobial components}

Snake venoms are a heterogeneous mixture of chemicals constitute mainly of proteins and peptides. The most heterogeneous venom contains 100 s to 1000 s of rare bioactive peptides. Snake venoms have evolved into complex mixtures of pharmacologically active proteins and peptides that exhibit potent, lethal and debilitating effects to assist in prey capture. Snakes use their venoms as offensive weapons in incapacitating and immobilizing their prey (the primary function), as a defensive tool against their predators (the secondary function) and to aid in digestion (the tertiary function). Snake venom has been a reservoir of 300 to over 100 protein toxins some which show enzymatic activities while others are only polypeptides. On the basis of their structure, they can be classified into small toxin super families. This is remarkable that being structurally similar they show distinct pharmacological effects. The most common enzymes in snake venoms are phospholipase A2s (PLA2s), serine proteinases, metalloproteinases, acetylcholinesterases (AChEs), L-amino acid oxidases, nucleotidases (5'-nucleotidases, ATPases, phosphodiesterases, and DNAases) and hyaluronidases. In most cases, snake venoms are the most abundant source for all these enzymes [19]. Owing to their higher catalytic efficiency, thermal stability, and resistance to proteolysis these enzymes present themselves as attractive models for researchers in all the fields. Snake venom had been used for medicinal purposes from long back and recently, there have been several new drugs derived from components of snake venom have been used to treat to patients worldwide. The function of some compounds is still unknown but is believed to act in a certain way on the body of its prey or a potential predator. Isolated snake venom proteins and peptides are used as pharmaceutical agents in spite of their toxicological effects, antigenic and digestible structure. Some of these compounds are in preclinical or clinical phases for treating diseases, like, multiple sclerosis, diabetes, cardiovascular diseases and pain. BPP9, bradykinin potentiating peptide, isolated from the Bothrops jararaca snake venom, has angiotensin-converting enzyme (ACE) inhibiting property and it was used for the development of antihypertensive Captopril, by Squibb Corporation.

Also, batroxobin, isolated from B. atrox and B. moojeni snake venoms is a serine protease and is used to treat vascular disorders. Additionally, the batroxobin, isolated from B. atrox and B. moojeni venoms, is a serine protease and was used to treat vascular thrombosis. Further, it has opened doors for designing drugs for many critical diseases such as cancer, where in these toxins may provide which venom toxin structural templates for the study of new molecules or mechanisms. Certain peptides such as vgf- 1 from venom of the Chinese cobra Naja atra is active against multidrug resistant Mycobacterium tuberculosis [20].

Snake venom isolated toxins or peptides can provide structural templates for the study of new molecules or cellular mechanisms and through drug discovery treatment of a lot of critical disease such as cancer possible, there is a great interest in drug design, in which venom toxins could. With recent advancement in the biotechnological areas new possibilities for contributions to clinical medicine and biomedical research from snake venom have come up. There are various commonly used drugs reported to be made from snake venom as illustrated in Table 1.

\section{Antimicrobial potency}

Several lines of evidence showed that snake venom proteins exhibited antimicrobial activities [21]. Among some of the common
Table 1. Commonly used drugs made from snake venom (Modified from Koh et al. [1])

\begin{tabular}{|c|c|c|}
\hline Snake Genus (species) & Drug Name & Drug Treatment \\
\hline Agkistrodon (contortrix) & Protac & Hemostasis \\
\hline $\begin{array}{c}\text { Bothrops (atrox, jararaca, } \\
\text { jararacussu, moojeni) }\end{array}$ & $\begin{array}{c}\text { Hemocoagulase, Reptilase, } \\
\text { Captopril, Defibrase }\end{array}$ & $\begin{array}{c}\text { Hemorrhage, coagulation, } \\
\text { ischemia, } \\
\text { high blood pressure }\end{array}$ \\
\hline Calloselasma (rhodostoma) & Ancrod/Viprinex & Hemostasis, stroke \\
\hline Echis (carinatus) & Aggrastat/Tirofiban, Ecarin & Heart attack, pro-coagulant \\
\hline Naja & Exanta & Anti-coagulant \\
\hline Sistrurus (miliarius) & Integrilin/Eptifibatide & Ischemia \\
\hline
\end{tabular}

antimicrobial components that have been isolated from snake venom are (i) L-amino acid oxidase (LAAO), and (ii) phospholipase A2 (PLA2) [22-27]. The LAAO antibacterial action appears to result from hydrogen peroxide generated by the oxidative action of the enzymes, as the effect is abolished in the presence of hydrogen peroxide scavengers such as catalase [23]. Membrane permeabilizing and damage mechanisms are believed to be responsible for the bactericidal effect of PLA2 enzymes [25]. Apart from enzymatic proteins, antimicrobial peptides including cathelicidins, vgf-1 (nerve growth factor-1) and omwaprin have been isolated from various venomous snake species [8,28,29]. Although antimicrobial proteins and peptides may kill bacteria by macromolecular biosynthesis inhibition and/or interacting with specific vital components inside the bacteria, most antimicrobial proteins and peptides are cationic in nature and exert their bactericidal effect by permeabilizing the bacterial membrane, thinning the membrane or destabilizing the membrane structure [30].

\section{L-amino acid oxidase}

L-amino acid oxidases (LAAO) are homodimeric flavoproteins that catalyze the stereospecific deamination of L-amino acid substrates to a keto-acid along with the production of $\mathrm{H}_{2} \mathrm{O}_{2}$ and ammonia. These enzymes are widely expressed in many different organisms from prokaryotes to metazoans, of which snake venom LAAO being the most studied. LAAO are widely distributed in the different genera and families of venomous snakes viz., Viperidae, Crotalidae, and Elapidae [31] and are responsible for several biological activities. They catalyze a redox reaction of different groups of amino acids, generating hydrogen peroxide $\left(\mathrm{H}_{2} \mathrm{O}_{2}\right)$ as a catabolic product. This reactive oxygen species (ROS) so far seems to be the molecule responsible for the pharmacological effects of this class of enzymes. Many of the early studies focused on the characterization of the redox and kinetic activities of Crotalus adamantus LAAO (caLAAO) [32-34]. These studies showed that the enzyme goes through a ternary complex of enzyme substrate and oxygen reduction of the flavin involves the formation of a semiquinone. As the protein is a flavor enzyme oxidase, the reduced FAD cofactor is re-oxidized with di-oxygen during the reductive half-reaction, resulting in the formation of $\mathrm{H}_{2} \mathrm{O}_{2}$.

\section{Importance of hydrogen peroxide}

The hydrogen peroxide generated during the enzymatic reaction is a highly toxic ROS that is capable of acting on nucleic acids, proteins, and plasma cell membranes [35]. This ROS formed extra-cellularly, may act directly on cell membranes by altering the permeability of the attacked area, and may also be involved in necrosis or apoptosis. The process of necrosis could be related to the direct action of $\mathrm{H}_{2} \mathrm{O}_{2}$ on the plasma cell membrane since, within the mechanism of apoptosis, the development of morphological, biochemical, and molecular changes leads to cell death [36]

A novel LAAO (BmLAO) from Bothrops mattogrosensis was isolated and biochemically characterized. Partial enzyme sequence 
showed full identity to Bothrops pauloensis LAAO. Moreover, LAAO showed remarkable antibacterial activity against Gram-positive and gram-negative bacteria [37]. King cobra L-amino acid oxidase (OhLAAO) isolated from Ophiophagus hannah venom was reported to show antibacterial activity against various Gram-positive and -negative bacteria [38]. BsLAAO, purified from Bothriechis schlegelii venom showed the inhibitory effect against $S$. aureus and Acinetobacter baumannii, but no effect was observed in Escherichia coli [39]. However, Balt-LAAO-I isolated from Bothrops alternatus snake venom was reported to exhibit bactericidal activity against Escherichia coli and Staphylococcus aureus [40]. DRS-LAAO purified from Daboia russellii siamensis venom was reported to have antibacterial activity against Staphylococci aureus (ATCC 25923), Pseudomonas aeruginosa (ATCC 27853) and Escherichia coli (ATCC 25922) [41].

The antibacterial effects of king cobra venom LAAO were reported against several strains of clinical isolates including $S$. aureus, $S$. epidermidis, P. aeruginosa, Klebsiella pneumoniae, and E. coli [23]. LAAO isolated from $B$. jararaca venom showed $S$. aureus growth inhibition and also bactericidal effect against other Gram-positive and -negative bacteria [42]. Highly purified L-amino acid oxidase (Bp-LAAO) from Bothrops pauloensis snake venom showed bactericidal activities dose dependently [43]. A new L-amino acid oxidase (LAAO) isolated from the Central Asian cobra Naja naja oxiana venom was reported to exhibit antibacterial activity inhibiting the growth of Gram-positive (Bacillus subtilis) and Gram-negative (Escherichia coli) bacteria [44].

Bacterial growth of Gram-negative (Xanthomonas axonopodis pv passiflorae) and Gram-positive (S. mutans) strains were inhibited by a novel L-amino acid oxidase (LAAO) (Casca LAO) from Crotalus durissus cascavella venom. Electron microscopic assessments of both bacterial strains suggested that the $\mathrm{H}_{2} \mathrm{O}_{2}$ produced by LAO induced bacterial membrane rupture and consequently loss of cytoplasmatic content [45]. The L-amino acid oxidase from Vipera lebetina venom was reported to possess antimicrobial activity inhibiting the growth of both Gram-negative and Gram-positive bacteria [46]. Akbu-LAAO an L-amino acid oxidase isolated from the venom of Agkistrodon blomhoffi ussurensis snake exhibited a strong bacteriostasis effect on $\mathrm{S}$. aureus, eighteen fold that of cephalosporin C, standard antibiotic under the same conditions [47].

L-amino acid oxidase (TM-LAO) from the venom of Hunan Trimeresurus mucrosquamatus inhibited the growth of $E$ coli, $S$. aureus and $B$. dysenteriae. TM-LAO also showed cytotoxicity and platelet aggregation activity. It was shown that these biological effects were possibly due to the formation of $\mathrm{H}_{2} \mathrm{O}_{2}$ produced by TM-LAO [48]. An L-amino acid oxidase (LAAO), designated as TJ-LAO, was purified to homogeneity from the venom of Trimeresurus jerdonii inhibited the growth of E. coli, S. aureus, P. aeruginosa, and B. megaterium. The antibacterial effect associated with LAAO activity was eliminated with the addition of catalase [49]. All the biological activities were eliminated by catalase, a $\mathrm{H}_{2} \mathrm{O}_{2}$ scavenger. Bmar LAAO an L-amino acid oxidase isolated from B. marajoensis venom inhibited the growth of several microorganisms, including $S$. aureus, Candida albicans and $P$. aeruginosa [22].

According to several investigators, $[45,50,51]$ the most likely mode of action involved in the bactericidal activity of LAAOs is that $\mathrm{H}_{2} \mathrm{O}_{2}$ causes oxidative stress in the target cell, triggering disorganization of the plasma membrane and cytoplasm and consequent cell death. Antibacterial profile of various snake venom LAAOs is discussed in Table 2.
Table 2. Anti-bacterial profile of various snake venom LAAOs

\begin{tabular}{|c|c|c|c|}
\hline Snake species & $\begin{array}{l}\text { Antibacterial } \\
\text { component }\end{array}$ & Effective against & References \\
\hline $\begin{array}{c}\text { Bothrops } \\
\text { mattogrosensis }\end{array}$ & BmLAAO & $\begin{array}{l}\text { Gram positive and } \\
\text { negative bacteria }\end{array}$ & {$[35]$} \\
\hline $\begin{array}{l}\text { Ophiophagus } \\
\text { Hannah }\end{array}$ & $\begin{array}{l}\text { King cobra L-amino } \\
\text { acid oxidase (Oh- } \\
\text { LAAO) }\end{array}$ & $\begin{array}{l}\text { Gram positive and } \\
\text { negative bacteria }\end{array}$ & {$[36]$} \\
\hline B. alternatus & Balt-LAAO-I & E. coli and $S$. aureus & {$[38]$} \\
\hline $\begin{array}{l}\text { Daboia russellii } \\
\text { siamensis }\end{array}$ & DRS-LAAO & $\begin{array}{c}\text { S. aureus (ATCC } \\
\text { 25923), } \\
\text { P. aeruginosa (ATCC } \\
\text { 27853) and E. coli } \\
\text { (ATCC 25922). }\end{array}$ & [39] \\
\hline King cobra venom & LAAO & $\begin{array}{c}\text { S. aureus, } S . \\
\text { epidermidis, } \\
\text { P. aeruginosa, } K . \\
\text { pneumoniae, and } \\
\text { E. coli }\end{array}$ & [21] \\
\hline B. pauloensis & Bp-LAAO & Not specific & [41] \\
\hline Bothriechis schlegelii & BsLAAO & $\begin{array}{l}\text { S. aureus and } \\
\text { Acinetobacter } \\
\text { baumannii }\end{array}$ & {$[37]$} \\
\hline Naja naja oxiana & LAAO & B. subtilis and E. coli & {$[42]$} \\
\hline $\begin{array}{l}\text { Crotalus durissus } \\
\text { cascavella }\end{array}$ & Casca LAAO & $\begin{array}{c}\text { (Xanthomonas } \\
\text { axonopodis } p v \\
\text { passiflorae) and } S . \\
\text { mutans }\end{array}$ & [43] \\
\hline $\begin{array}{l}\text { C. durissus } \\
\text { cumanensis }\end{array}$ & CdcLAAO & $\begin{array}{l}\text { S. aureus and } A \text {. } \\
\text { baumannii }\end{array}$ & {$[37]$} \\
\hline Vipera lebetina & LAAO & $\begin{array}{c}\text { Gram-negative } \\
\text { and Gram-positive } \\
\text { bacteria }\end{array}$ & [44] \\
\hline $\begin{array}{c}\text { Agkistrodon } \\
\text { blomhoffiiussurensis }\end{array}$ & Akbu-LAAO & S. aureus & [45] \\
\hline $\begin{array}{c}\text { Trimeresurus } \\
\text { mucrosquamatus }\end{array}$ & TM-LAO & $\begin{array}{l}\text { E. coli, } \text { S. aurues and } \\
\text { B. dysenteriae }\end{array}$ & [46] \\
\hline T. jerdonii & TJ-LAO & $\begin{array}{l}\text { E. coli, } S . \text { aureus, } P \text {. } \\
\text { aeruginosa, and } B . \\
\text { megaterium. }\end{array}$ & {$[47]$} \\
\hline B. marajoensis & BmarLAAO & $\begin{array}{c}\text { S. aureus, and } P \text {. } \\
\text { aeruginosa }\end{array}$ & [20] \\
\hline B. jararaca & LAAO & S. aureus & {$[40]$} \\
\hline $\begin{array}{l}\text { Agkistrodon haly } \\
\text { Pallas }\end{array}$ & LAAO & E coli K12D31 & [49] \\
\hline B. leucurus & BleuLAAO & S. aureus & {$[20]$} \\
\hline
\end{tabular}

\section{Phospholipase A2 (PLA2)}

Phospholipase A2 (PLA2) enzymes (EC 3.1.1.4) are among the bestcharacterized components of snake venoms. Secretory phospholipases A2 (sPLA2s; EC 3.1.1.4) is a family of lipolytic enzymes that specifically catalyze the hydrolysis of fatty acid ester bonds to produce free fatty acids and lysophospholipids [52] and commonly classified into 12 groups and many subgroups [53]. Snake venom PLA2s are proteins belonging to the groups I and II. Those of group I are found in the Elapidae family (Elapinae and Hydrophiinae), whereas those of group II are found in the Viperidae family (Viperinae and Crotalinae). The latter can be further subdivided into two types: Asp49 PLA2s, which are catalytically active, and PLA2 homologs, which possess most commonly a Lys49 residue and does not have catalytic activity [52,54]. Strong evidence has accumulated that GIIA PLA2 plays an important role in the defense against bacteria.

A novel sPLA2-I named BFPA was identified from Bungarus fasciatus venom, and its antimicrobial activity was studied as well. Unlike the well-known sPLA2-Is, which have 14 half-cysteines forming 7 intra-molecular disulfide bridges, BFPA possessed 15 half cysteines. 
The additional cysteine might contribute to the formation of an intermolecular disulfide bridge of the homodimeric protein. In the biological activities assays, BFPA displayed bactericidal activity against E. coli and S. aureus [55].

A novel PLA2 named PnPLA2 was purified from the venom of Porthidium nasutum by means of RP-HPLC showing homology to other acidic PLA2s from viperid venoms. PnPLA2 displayed bactericidal activity against $\mathrm{S}$. aureus in a dose-dependent manner, with a MIC and $\mathrm{MBC}$ of $32 \mu \mathrm{g} / \mathrm{ml}$ [56]. A short peptide derived from the C-terminal region of Bothrops asper myotoxin II, a Lys49 phospholipase A2 (PLA2), was previously found to reproduce the bactericidal activity of its parent molecule. In this study, a panel of eight PLA2 myotoxins purified from crotalid snake venoms, including both Lys49 and Asp49type isoforms, were all found to express bactericidal activity, indicating that this may be a common action of the group IIA PLA2 protein family [26]. The inhibitory effects of Secretory phospholipasesA2 (sPLA2s) from Vipera lebetina (VL PLA2), Vipera berus berus (VBB-PLA2), and Naja naja oxiana (NNO-PLA2) venoms on four different bacterial strains (Gram-negative Escherichia coli and Vibrio fischeri; Grampositive Staphylococcus aureus and Bacillus subtilis) were studied. Among all VBB-PLA2 completely inhibited the growth of Grampositive $B$. subtilis whereas no growth inhibition was observed towards Gram-negative E. coli [57]. A basic myotoxic PLA(2), named EcTx-I was isolated from Echis carinatus snake venom exhibited bactericidal activity against Enterobacter aerogenes, E. coli, Proteus vulgaris, Proteus mirabilis, Pseudomonas aeruginosa, and Staphylococcus aureus [58].

Agkistrodon snake venoms contain a variety of phospholipases (PLA2), some of them are myotoxic. The enzyme named as AgkTxII, a basic Asp49 PLA2, was reported from Agkistrodon snake venom having antibacterial activities. AgkTx-II rapidly killed $S$. aureus, $P$. vulgaris, and B. pseudomallei in a dose-dependent manner and, the AgkTx- II was believed to exert its bactericidal effect by permeabilizing the bacterial membrane by forming pores [30]. A novel sPLA(2)-I named BFPA was identified from Bungarus fasciatus venom, and its antimicrobial activity against $E$. coli and $S$. aureus was studied as well. This study was the first report about the Gram-positive bactericidal activity of sPLA(2)-I [59]. Structural and functional characterization of basic phospholipases A2 (PLA2S) isolated from Crotalus durissus terrificus venom showed antimicrobial activity against Xanthomonas axonopodis pv. Passiflorae [60]. Antibacterial profile of various snake venom PLA2s is discussed in Table 3.

\section{Antimicrobial peptides or proteins}

Antimicrobial peptides are defined as molecules that have a critical defense against all kinds of microorganisms, protecting the host from the invasion of bacteria, fungi, and viruses. They play a major role in innate immunity and exhibiting the bactericidal effect. Over the past years, natural antimicrobial peptides (AMPs) have attracted considerable interests as a new type of antimicrobial agents for several reasons including their relative selectivity towards targets (microbial membranes), their rapid mechanism of action, broad antimicrobial spectra and, above all, the low frequency in selecting resistant strains. For clinical applications, it is important to develop potent AMPs with less toxicity against host cells. Antimicrobial peptides can be divided into four structural groups known as $\alpha$-helical, $\beta$-sheet, $\alpha$-hairpin, and extended peptides [61].

Moreover, in addition to their diversity in amino acid sequences and structures, these AMPs share amphipathic properties [62,63]. Due to this amphipathic characteristic they bind to membranes of microorganisms and has been thought to cause cell lysis by interaction with lipids (Figure 2). Furthermore, AMPs can self-associate and form pores or can possibly act in disintegrating membranes in a detergentlike manner [64]. Although a fold into the amphipathic structure seems to be a prerequisite for cell lysis, the exact mechanisms of action of most AMPs are still unclear.

\section{Cathelicidin}

Cathelicidins are a family of antimicrobial peptides acting as multifunctional effectors molecule in innate immunity. Cathelicidin$\mathrm{BF}$ had been purified from the snake venoms of Bungarus fasciatus and it was the first identified cathelicidin antimicrobial peptide in reptiles. In this study, cathelicidin-BF was found exerting strong antibacterial activities against

\section{Propionibacterium acnes}

Its minimal inhibitory concentration against two strains of $\mathrm{P}$. acnes was $4.7 \mathrm{mg} / \mathrm{ml}$. Staphylococcus epidermidis, which was possible pathogen for acne vulgaris, was also effectively killed by Cathelicidin-BF [65]. Xia et al. [66] reported that the possibility of a potent antimicrobial peptide cathelicidin-BF found in the venom of the snake Bungarus fasciatus in treating Salmonella typhimurium infection. Cathelicidin$\mathrm{BF}$ attenuated the clinical symptoms of Salmonella infected-mice, significantly reducing the number of internalized Salmonella and attenuated Salmonella-induced decreases in TER in epithelial cells.

Three cDNA sequences coding for elapid cathelicidins were cloned from constructed venom gland cDNA libraries of Naja atra, Bungarus fasciatus, and Ophiophagus hannah. Unlike the highly divergent cathelicidins in mammals, the nucleotide and deduced protein sequences of the three cloned elapid cathelicidins were remarkably conserved. It showed strong antibacterial activity against various bacteria with a minimal inhibitory concentration of 1-20 $\mu \mathrm{g} \mathrm{ml-1} \mathrm{[67].}$

The antibacterial activity of BF-30 Cathelicidin from the venom of Bungarus fasciatus was studied against drug-resistant E. coli, P. aeruginosa, and $\mathrm{S}$. aureus. The data showed that BF-30 had stronger antimicrobial activities against a broad spectrum of microorganisms than gentamicin, ampicillin or bacitracin. The killing curves of BF-30 against $\mathrm{P}$. aeruginosa and $\mathrm{S}$. aureus showed that CFU counts rapidly decreased by almost 2 logs within $6 \mathrm{~min}$, and it took just less than $2 \mathrm{~h}$ to kill all the bacteria [68].

Table 3. Antibacterial profile of various snake venom Phospholipae A2s

\begin{tabular}{|c|c|c|c|}
\hline Snake species & Antibacterial component & Effective against & References \\
\hline Bungarus fasciatus & BFPA & E. coli and S. aureus & [57] \\
\hline Agkistrodon spp & AgkTx-II & S. aureus, $P$. vulgaris and B. pseudomallei & {$[23]$} \\
\hline Echis carinatus & EcTx-I & $\begin{array}{c}\text { E. aerogenes, E. coli, } P \text {. vulgaris, } P \text {. mirabilis, } P . \\
\text { aeruginosa and } S \text {. aureus }\end{array}$ & {$[56]$} \\
\hline Vipera berus berus & VBBPLA2 & B. subtilis & {$[55]$} \\
\hline Bothrops asper & PLA2 myotoxins & S. typhimurium and S. aureus & {$[24]$} \\
\hline Porthidium nasutum & PnPLA2 & S. aureus & {$[54]$} \\
\hline
\end{tabular}


A

Human plasma membrane

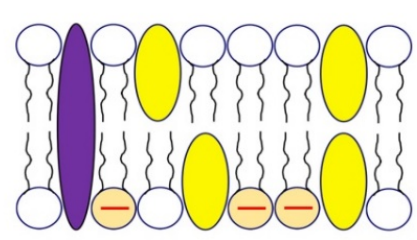

Bacterial plasma membrane

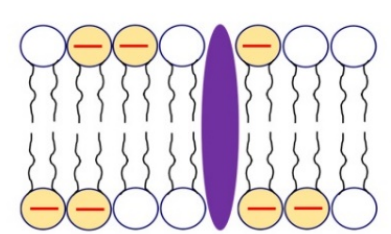

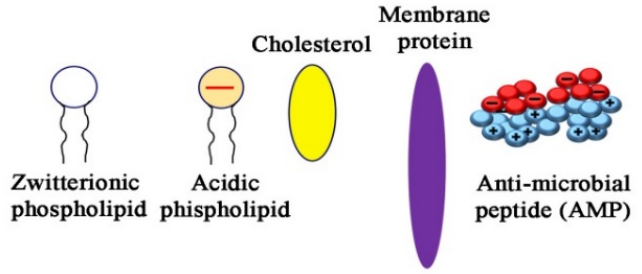

B
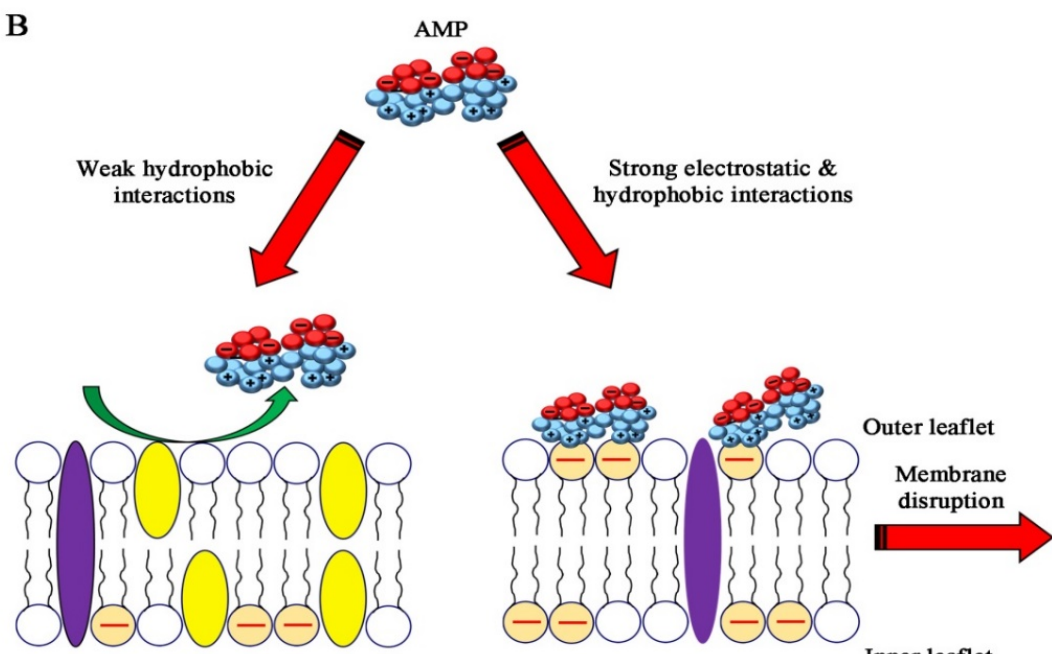

Inner leaflet

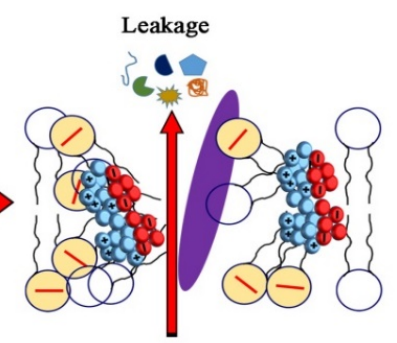

Figure 2. AMPs can bind to membranes of microorganisms as they are amphipathic and has been thought to cause cell lysis by interaction with lipids but not with the membranes of human

\section{Whey acidic protein related protein (WAPRIN)}

Waprin is a new family of snake venom proteins [69]. The amino acid sequences of waprins do not show similarity with any other snake venom proteins. They show similarity with the WAP (whey acidic protein) domain-containing proteins. The WAP domain is made up of eight conserved cysteine residues forming four disulfide bonds, found generally in 50 amino acid residues stretch of proteins. The WAP domain is found in proteins with divergent functions including SPAI (Na+, K+-ATPase inhibitor), which inhibits $\mathrm{Na}+\mathrm{K}+$ ATPase [70], elafin and SLPI (secretory leucocyte proteinase inhibitor) are proteinase inhibitors with potent antimicrobial activity [71,72] and SWAM1 and SWAM2 (single WAP motif proteins 1 and 2), which are antibacterial proteins [73].

\section{Omwaprin}

Omwaprin, a 50-amino-acid cationic protein from the venom of Inland Taipan (Oxyuranus microlepidotus), a new member of the waprin family of snake venom proteins showed selective, speciesspecific and dose-dependent antibacterial activity against Grampositive bacteria. The minimum inhibitory doses were reported in the range $2-10 \mu \mathrm{g}$ for selected species of bacteria in radial diffusion assays. The mechanism of action was via membrane disruption, illustrated by scanning electron microscopy [28].

\section{Nerve growth factor (Vgf-1)}

A small peptide with the amino acid sequence designated as vgf1 from Naja atra (isolated from Yunnan province of China) venom exhibited in vitro activity against clinically isolated multidrug-resistant strains of M. tuberculosis $[20,8]$.

\section{Cardiotoxins (CTXs)}

CTXs, a group of major venom polypeptides of around 60 amino acid residues present abundantly in the elapid family of snakes, show pharmacological functions including hemolysis, cytotoxic and depolarization of muscles [74]. CTXs may damage cells by their ability to interact with anionic lipids or negatively charged oligosaccharides on the cell membrane and subsequently form an oligomeric toxin complex [75-77]. The relationship between membrane-damaging activity and bactericidal activity of Naja naja atra (Taiwan cobra) cardiotoxin 3 (CTX3) was investigated. CTX3 showed greater inhibitory activity for the growth of $S$. aureus (Gram-positive bacteria) relative to that of E. coli (Gram-negative bacteria). Their data indicated that CTX3 bactericidal activity was depended highly on its ability to induce membrane permeability [78]. Toxin $\gamma$, a CTX isolated from the venom of Naja nigricollis, showed a similar inhibitory activity on the growth of S. aureus (Gram-positive bacteria) and E. coli (Gram-negative bacteria). Antibacterial activity of toxin $\gamma$ correlated positively with an increase in membrane permeability of bacterial cells [78]. Membranebound mode and membrane perturbing effect of CTX3 and toxin $\gamma$ in concert with targeted membrane compositions determined their fusogenicity and membrane-damaging activity and suggested a causal relationship between bactericidal activity and fusogenicity of CTX3 and toxin $\gamma$ [79].

\section{$\beta$-Bungarotoxin ( $\beta$-Bgt)}

$\beta$-Bgt the main presynaptic PLA2 neurotoxin purified from the venom of Bungarus multicinctus (Taiwan banded krait), exerted antibacterial activity against E. coli (Gram-negative bacteria) and S. aureus (Gram-positive bacteria) via its membrane-damaging activity. The B-chain exhibited a growth inhibition effect on E. coli but did 
not show a bactericidal effect on $S$. aureus. The B-chain bactericidal action on E coli positively correlated with an increase in membrane permeability in the bacterial cells [80].

\section{Myotoxins}

Crotamine, a myotoxin from the venom of the South American rattlesnake, is structurally related to $\beta$-defensins, antimicrobial peptides (AMPs) found in vertebrate animals. Because of structural similarity with $\beta$-defensins, it is conceivable that crotamine might function as an AMP, in addition to being a mycotoxin. The purified crotalic venom from the snake Crotalus durissus terrrificus exhibited antibacterial activity against several strains of E. coli, with the MICs ranging from 25 to $100 \mu \mathrm{g} \mathrm{ml}-1$. The three intramolecular disulfide bonds of crotamine appeared dispensable for its antibacterial activity [81]. Bothrops jararacussu myotoxin I (BthTx-I; Lys 49) and II (BthTXII; Asp 49) were purified by ion-exchange chromatography and reverse phase HPLC. Further antibacterial effects were exhibited by of BthTx-I and BthTx-II against Xanthomonas axonopodis. pv. passiflorae (Gramnegative bacteria) [82].

\section{Lectins}

Lectins are proteins or glycoproteins that bind reversibly to carbohydrates and glycol-conjugates and have been found in a wide range of organisms from microorganisms to plants and animals. Glycoconjugates present on bacterial cell surfaces, such as peptidoglycans, lipopolysaccharides, and teichoic acids, constitute potential lectin targets. A novel lectin isolated from Bothrops leucurus snake venom (BlL) showed effective antibacterial activity against Gram-positive bacteria Staphylococcus aureus, Enterococcus faecalis and Bacillus subtilis. Crotacetin, a novel snake venom C-type lectin homolog of convulxin, isolated from the venom of South American rattlesnake Crotalus durissus terrificus also exhibited an unpredictable antimicrobial activity against Gram-positive and gram-negative bacteria.

\section{Snake venom metalloproteinases (SVMPs)}

SVMPs have been considered as the key toxins involved in snake venom-induced pathogenesis, including hemorrhage, edema, hypotension, hypovolemia, inflammation, and necrosis. Although SVMPs are known for their proteolytic, cell-matrix and cell-cell adhesion abilities, only a few studies have related these enzymes to direct antimicrobial activities. Metalloproteinase from the venom of Agkistrodon halys showed the antibacterial effect on S. aureus, P. vulgaris, P. mirabilis and multi-drug resistant B. pseudomallei (strain KHW) bacteria [25].

\section{Snake venom against plant pathogens}

The bactericidal effect of two subunits of crotoxin (PLA2 and Crotapotin) isolated from the South American rattlesnake Crotalus durissus terrificus were reported against two plant pathogenic bacteria Xcampestris pv phasioli and Xcampestirs pv passiflorae [60]. Cathelicidin-BF and cathelicidin- BF15 isolated from the venom of Bungarus fasciatus were reported to be effective to some fungi, for example, C. albicans ATCC 2002 (with a MIC of $4.7 \mathrm{mg} / \mathrm{ml}$ ) and $P$. pastoris (with a MIC of $0.3 \mathrm{mg} / \mathrm{ml}$ ). Cathelicidin-BF exerted obvious antimicrobial activity against some saprophytic fungus such as Aterreus, Aniculans and C. globosum [29]. These studies indicated a possible role of SV as agricultural antibiotics against plant or food pathogenic microorganisms.

\section{Future perspectives}

Snake venom, unique natural product secreted by the salivary glands of venomous snakes, is a mixture of various molecules having diverse but highly specific biological activities. They are composed of a mixture of proteins such as PLA2, metalloproteinases, serine proteases, LAAOs, lectins and other peptides (90-95\%) and enzymes (5\%).

The presence and emergence of multidrug-resistant strains make the risk of bacterial infections a universal problem with deleterious effects. The burden of bacterial diseases is high in the world with India being on the top. A large population is immuno-compromised on account of diseases such as diabetes, renal failure, heart diseases, cancer, and HIV infection and these people are at higher risk of infection. Therefore, the development of alternative drug line to treat such infectious diseases or search for alternatives to synthetic antibiotics is urgently required. Traditional methods of antibiotic discovery have failed to keep pace with the evolution of resistance, so new strategies to control bacterial infections are highly desirable. The antimicrobial molecules obtained from snake venom have demonstrated an interesting alternative for controlling microorganisms that are resistant to conventional antibiotics, contributing to medicine due to their differential mechanisms of action and versatility. Although snake venoms exhibit toxicological effects, still several isolated snake venom proteins, enzymes, and peptides have found practical application as pharmaceutical agents. Various proteins and peptides presenting antimicrobial activity in snake venoms have been described in the literature. Among some of the common antimicrobial components that have been isolated from snake venom are LAAO and PLA2. Apart from major enzymatic proteins, few lectins, SVMPs and various AMPs viz cathelicidins cardiotoxins (CTXs), vgf-1, omwaprin, $\beta$-Bungarotoxin ( $\beta$-Bgt), myotoxins etc. have been isolated, purified and characterized from the venom of various snake species.

The recent development of mass spectrometry and structural bioinformatics will perhaps be helpful in elucidating the chemical structure and peptide families of purified proteins from various snake venoms. So far, a majority of snake venom antimicrobial /proteins or cytotoxins or AMPs reported and isolated from various species, have been observed to have bacterial membrane system as their chief target. The NMR techniques could also shed some light on how peptides behave in bacterial and eukaryotic membranes, displaying the kind of interactions these antimicrobial components can develop with these lipids bilayers. Apart from the emphasis on snake venom's antibacterial therapeutic properties, ample focus should also be given on novel technologies of chemical synthesis and heterologous expression system. This can realize into mass scale production, which is the ultimate goal of alternative antibacterial prototype discovery strategy. Therefore, future studies must also focus on the mechanism of action of these compounds and how they really act on both in vitro mammalian cell culture system and in vivo animal model to check whether or not snake venom component have any toxic effect on mammalian system, particularly at the concentrations these snake venom components show antimicrobial activity.

\section{Conclusion}

Although no proteinaceous antimicrobial compounds from snake venom have been licensed for clinical use until now, current studies continue bringing new expectations about their viability as a new class of drugs. In summary, there is a huge untapped antibacterial potential found in snake venom is waiting to be exploited by pharmaceutical companies which may lead to the development of effective therapeutic alternatives to synthetic antibiotics. 


\section{Conflict of interest}

This manuscript has not been published and is not under consideration for publication elsewhere and we have no conflicts of interest to disclose.

\section{References}

1. Koh DC, Armugam A, Jeyaseelan K (2006) Snake venom components and their applications in biomedicine. Cell Mol Life Sci 63: 3030-3041. [Crossref]

2. Gomes A, Bhattacharjee P, Mishra R, Biswas AK, Dasgupta SC, et al. (2010) Anticancer potential of animal venoms and toxins. Indian J Exp Biol 48: 93-103. [Crossref]

3. Reid PF (2007) Alpha-cobratoxin as a possible therapy for multiple sclerosis: a review of the literature leading to its development for this application. Crit Rev Immunol 27: 291-302.

4. Talan DA, Citron DM, Overturf GD (1991) Antibacterial activity of crotalid venoms against oral snake flora and other clinical bacteria. J Infect Dis 164: 195-198.

5. Ferreira BL, Santos DO, Dos Santos AL, Rodrigues CR, de Freitas CC, et al. (2011) Comparative analysis of viperidae venoms antibacterial profile: a short communication for proteomics. Evid Based Complement Alternat Med 2011: 1-4. [Crossref]

6. Bush K, Courvalin P, Dantas G, Davies J, Eisenstein B, et al. (2011) Tackling antibiotic resistance. Nat Rev Microbiol 9: 894-896. [Crossref]

7. Spellberg B, Shlaes D (2014) Prioritized current unmet needs for antibacterial therapies. Clin Pharmacol Ther 96: 151-153. [Crossref]

8. Xie JP, Yue J, Xiong YL, Wang WY, Yu SQ (2003) In vitro activities of small peptides from snake venom against clinical isolates of drug-resistant Mycobacterium tuberculosis. Int J Antimicrob Agents 22: 172-174. [Crossref]

9. Guardabassi L, Kruse H (2003) Overlooked aspects concerning development and spread of antimicrobial resistance. Central European Symposium on Antimicrobial Resistance, Brijuni, Croatia, 4-7 July, 2003. Expert. Rev Anti Infec. Ther 1: 359-362.

10. Hancock RE, Diamond G (2000) The role of cationic antimicrobial peptides in innate host defences. Trends. Microbiol 8: 402-410.

11. Hujer AM, Bethel CR, Hujer KM, Bonomo RA (2004) Antibiotic resistance in the institutionalized elderly. Clin Lab Med 24: 343-361. [Crossref]

12. Charvat RA, Strobel RM (2018) Analysis of snake venom composition and antimicrobial activity. Toxicon 150: 151-167.

13. Butler MS, Buss AD (2006) Natural products--the future scaffolds for novel antibiotics? Biochem Pharmacol 71: 919-929.

14. Pace JL, Yang G (2006) Glycopeptides: Update on an old successful antibiotic class. Biochem Pharmacol 71: 968-980.

15. Jovetic S, Zhu Y, Marcone GL (2010) B-Lactam and glycopeptide antibiotics: first and last line of defense? Trends Biotechnol 28: 596-604

16. Cornaglia G, Rossolini GM (2009) Forthcoming therapeutic perspectives for infections due to multidrug-resistant Gram-positive pathogens. Clin Microbiol Infect 15: 218-223.

17. Samy RP, Pachiappan A Gopalakrishnakone P (2006) In vitro antimicrobial activity of natural toxins and animal venoms tested against Burkholderia pseudomallei. $B M C$ Infect Dis 6: 100.

18. Wenhua R, Shuangquan Z, Daxiang S, Kaiya Z, Guang Y (2006) Induction, purification and characterization of an antibacterial peptide scolopendrin I from the venom of centipede Scolopendra subspinipes mutilans. Indian J Biochem Biophys 43: 88-93.

19. Kang TS, Georgieva D, Genov N, Murakami MT (2011) Enzymatic toxins from snake venom: structural characterization and mechanism of catalysis. FEBS $J$ 278: $4544-$ 4576.

20. Mladic M, Slagboom J, Kool J, Vonk FJ, van Wezel (2018) Detection and identification of antibacterial proteins in snake venoms using at-line nano fractionation coupled to LC-MS. Toxicon 155: 66-74.

21. San TM, Vejayan J, Shanmugan K, Ibrahim H (2010) Screening antimicrobial activity of venoms from snakes commonly found in Malaysia. J Appl Sci 10: 2328-2332.

22. Costa Torres AF, Dantas RT (2010) Antibacterial and antiparasitic effects of Bothrops marajoensis venom and its fractions: Phospholipase A2 and L-amino acid oxidase. Toxicon 55: 795-804.

23. Lee ML, Tan NH, Fung SY, Sekaran SD (2011) Antibacterial action of a heat-stable form of L-amino acid oxidase isolated from king cobra (Ophiophagus hannah) venom. Comp Biochem Physiol C Toxicol Pharmacol 153: 237-242.
24. Samy PR, Gopalakrishnakone P (2007) Antibacterial activity of snake, scorpion and bee venoms: a comparison with purified venom phospholipase A2 enzymes. $J$ Appl Microbiol 102: 650-659.

25. Samy PR, Gopalakrishnakone P, Ho B, Chow VT (2008) Purification, characterization and bactericidal activities of basic phospholipase A2 from the venom of Agkistrodon halys (Chinese pallas). Biochimie 90: 1372-1388

26. Santamaría C, Larios S, Angulo Y, Pizarro-Cerda J, Gorvel JP (2005) Antimicrobial activity of myotoxic phospholipases A2 from crotalid snake venoms and synthetic peptide variants derived from their C-terminal region. Toxicon 45: 807-815.

27. Stiles BG, Sexton FW, Weinstein SA (1991) Antibacterial effects of different snake venoms: purification and characterization of antibacterial proteins from Pseudechis australis (Australian king brown or mulga snake) venom. Toxicon 29: 1129-1141.

28. Nair DG, Fry BG, Alewood P, Kumar PP, Kini RM (2007) Antimicrobial activity of omwaprin, a new member of the waprin family of snake venom proteins. Biochem $J$ 402: 93-104. [Crossref]

29. Wang Y, Hong J, Liu X, Yang H, Liu R (2008) Snake cathelicidin from Bungarus fasciatus is a potent peptide antibiotics. PLoS One 3: e3217.

30. Brogden KA (2005) Antimicrobial peptides: pore formers or metabolic inhibitors in bacteria? Nat Rev Microbiol 3: 238-250. [Crossref]

31. Tan NH (1998) L-amino acid oxidases and lactate dehydrogenases. In: Enzymes from snake venom; G. S. Bailey, Ed.; Fort Collins, CO: Alaken 19: 579-98.

32. deKok A, Rawitch AB (1969) Studies on L-amino acid oxidase. II. Dissociation and characterization of its subunits. Biochemistry 8: 1405-1411. [Crossref]

33. de Kok A, Veeger C (1968) Studies on L-amino-acid oxidase. I. Effects of pH and competitive inhibitors. Biochim Biophys Acta 167: 35-47.

34. Massey V, Curti B (1967) On the reaction mechanism of Crotalus adamanteus L-amino acid oxidase. $J$ Biol Chem 242: 1259-64.

35. Findrik Z, Geueke B, Hummel W (2006) Modelling of L-DOPA enzymatic oxidation catalyzed by L-amino acid oxidases from Crotalus adamanteus and Rhodococcus opacus. Biochem Engin J 27: 275-286.

36. Ande SR, Fussi H, Knauer H, Murkovic M, Ghisla S (2008) Induction of apoptosis in yeast by L-amino acid oxidase from the Malayan pit viper Calloselasma rhodostoma. Yeast 25: 349-357.

37. Okubo BM, Silva ON (2012) Evaluation of an antimicrobial L-amino acid oxidase and peptide derivatives from Bothropoides mattogrosensis pitviper venom. PLoS One 7: e33639.

38. Phua CS, Vejayan J, Ambu S, Ponnudurai G, Gorajana A (2012) Purification and antibacterial activities of an L-amino acid oxidase from king cobra (Ophiophagus hannah) venom. J Venom Anim Toxins Incl Trop Dis 18: 198-207.

39. Vargas Muñoz LJ, Estrada-Gomez S, Núñez V, Sanz L, Calvete JJ (2014) Characterization and cDNA sequence of Bothriechis schlegeliil-amino acid oxidase with antibacterial activity. Int J Biol Macromol 69: 200-207.

40. Stábeli RG, Marcussi S, Carlos GB, Pietro RC, Selistre-de-Araújo HS, et al. (2004) Platelet aggregation and antibacterial effects of an 1-amino acid oxidase purified from Bothrops alternatus snake venom. Bioorg Med Chem 12: 2881-2886.

41. Zhong SR, Jin Y, Wu JB, Jia YH, Xu GL, et al. (2009) Purification and characterization of a new L-amino acid oxidase from Daboia russellii siamensis venom. Toxicon 54: 763-771.

42. Ciscotto P, Machado de Avila RA, Coelho EA, Oliveira J, Diniz CG, et al. (2009) Antigenic, microbicidal and antiparasitic properties of an 1-amino acid oxidase isolated from Bothrops jararaca snake venom. Toxicon 53: 330-341.

43. Rodrigues RS, da Silva JF, Boldrini França J, Fonseca FP, Otaviano AR, et al. (2009) Structural and functional properties of Bp-LAAO, a new L-amino acid oxidase isolated from Bothrops pauloensis snake venom. Biochimie 91: 490-501. [Crossref]

44. Samel M, Vija H, Kurvet I, Künnis-Beres K, Trummal K, et al. (2013) Interactions of PLA2-s from Vipera lebetina, Vipera berus berus and Naja naja oxiana venom with platelets, bacterial and cancer cells. Toxins (Basel) 5: 203-223.

45. Toyama MH, Toyama Dde O, Passero LF, Laurenti MD, Corbett CE, et al. (2006) Isolation of a new L-amino acid oxidase from Crotalus durissus cascavella venom. Toxicon 47: 47-57. [Crossref]

46. Tõnismägi K, Samel M, Trummal K, Rönnholm G, Siigur J, et al. (2006) L-amino acid oxidase from Vipera lebetina venom: isolation, characterization, effects on platelets and bacteria. Toxicon 48: 227-37. [Crossref] 
47. Sun MZ (2010) Biochemical, functional and structural characterization of AkbuLAAO: a novel snake venom L-amino acid oxidase from Agkistrodon blomhoffii ussurensis. Biochimie 92: 343-349.

48. Wei JF, Wei Q, Lu QM, Tai H, Jin Y, et al. (2003) Purification, characterization and biological activity of an L-amino acid oxidase from Trimeresurus mucrosquamatus venom. Sheng Wu Hua Xue Yu Sheng Wu Wu Li Xue Bao (Shanghai) 35: 219-224. [Crossref]

49. Lu QM, Wei Q, Jin Y, Wei JF, Wang WY, et al. (2002) L-amino acid oxidase from Trimeresurus jerdonii snake venom: purification, characterization, platelet aggregationinducing and antibacterial effects. J Nat Toxins 11: 345-352. [Crossref]

50. Kitani Y, Kikuchi N, Zhang G, Ishizaki S, Shimakura K, et al. (2008) Antibacterial action of L-amino acid oxidase from the skin mucus of rockfish Sebastes schlegelii. Comp Biochem Physiol B Biochem Mol Biol 149: 394-400. [Crossref]

51. Zhang H, Teng M, Niu L, Wang Y, Wang Y, et al. (2004) Purification, partial characterization, crystallization and structural determination of AHP-LAAO, a novel L-amino-acid oxidase with cell apoptosis-inducing activity from Agkistrodon halys pallas venom. Acta Crystallogr D Biol Crystallogr 60: 974-977.

52. Kini RM (2003) Excitement ahead: structure, function and mechanism of snake venom phospholipase A2 enzymes. Toxicon 42: 827-840

53. Six DA, Dennis EA (2000) The expanding superfamily of phospholipase A(2) enzymes: classification and characterization. Biochim Biophys Acta 1488: 1-19.

54. Lomonte B, Angulo Y, Sasa M, Gutiérrez JM (2009) The phospholipase A2 homologues of snake venoms: biological activities and their possible adaptive roles. Protein Pept Lett 16: 860-876.

55. Burke JE, Dennis EA (2009) Phospholipase A2 structure/function, mechanism, and signaling. J Lipid Res 50: 237-242. [Crossref]

56. Vargas LJ, Londoño M, Quintana JC, Rua C, Segura C, et al. (2012) An acidic phospholipase A2 with antibacterial activity from Porthidium nasutum snake venom. Comp Biochem Physiol B Biochem Mol Biol 161: 341-347.

57. Samel M, Tõnismägi K, Rönnholm G, Vija H, Siigur J, et al. (2008) L-Amino acid oxidase from Naja naja oxiana venom. Comp Biochem Physiol B Biochem Mol Biol 149: 572-580. [Crossref]

58. Samy PR, Gopalakrishnakone P, Bow H, Puspharaj PN, Chow VT (2010) Identification and characterization of a phospholipase A2 from the venom of the Saw-scaled viper: Novel bactericidal and membrane damaging activities. Biochimie 92: 1854-1866.

59. Xu C, Ma D, Yu H, Li Z, Liang J, et al. (2007) A bactericidal homodimeric phospholipases A2 from Bungarus fasciatus venom. Peptides 28: 969-973. [Crossref]

60. Oliveira DG (2002) Structural and functional characterization of basic PLA2 isolated from Crotalus durissus terrificus venom. J Protein Chem 21: 161-168.

61. Bhattacharjya S, Ramamoorthy A (2009) Multifunctional host defense peptides: functional and mechanistic insights from NMR structures of potent antimicrobial peptides. FEBS J 276: 6465-6473. [Crossref]

62. Ramamoorthy A (2009) Beyond NMR spectra of antimicrobial peptides: dynamical images at atomic resolution and functional insights. Solid State Nucl Magn Reson 35: 201-207. [Crossref]

63. Shai Y (1999) Mechanism of the binding, insertion and destabilization of phospholipid bilayer membranes by alpha-helical antimicrobial and cell non-selective membranelytic peptides. Biochim. Biophys Acta 1462: 55-70.

64. Epand RM, Vogel HJ (1999) Diversity of antimicrobial peptides and their mechanisms of action. Biochim Biophys Acta 1462: 11-28.
65. Wang Y, Zhang Z, Chen L, Guang H, Li Z, et al. (2011) Cathelicidin-BF, a snake cathelicidin-derived antimicrobial peptide, could be an excellent therapeutic agent for acne vulgaris. PLoS One 6: e22120. [Crossref]

66. Xia X, Zhang L, Wang Y (2015) The antimicrobial peptide cathelicidin-BF could be a potential therapeutic for Salmonella typhimurium infection. Microbiol Res 171: 45-51. [Crossref]

67. Zhao H, Gan TX, Liu XD, Jin Y, Lee WH, et al. (2008) Identification and characterization of novel reptile cathelicidins from elapid snakes. Peptides 29: 1685-1691. [Crossref]

68. Zhou H, Dou J, Wang J, Chen L, Wang H, et al. (2011) The antibacterial activity of $\mathrm{BF}-30$ in vitro and in infected burned rats is through interference with cytoplasmic membrane integrity. Peptides 32: 1131-1138. [Crossref]

69. Torres AM, Wong HY, Desai M, Moochhala S, Kuchel PW, et al. (2009) Identification of a novel family of proteins in snake venoms. Purification and structural characterization of nawaprin mechanism, and signaling. J Lipid Res 50: 237-242. [Crossref]

70. Vargas LJ, Londoño M, Quintana JC (2012) An acidic phospholipase A2 with antibacterial activity from Porthidium nasutum snake venom. Comp. Biochem. Physiol. B Biochem Mol Biol 161: 341-347.

71. Samel M, Tõnismägi K, Rönnholm G, Vija H, Siigur J, et al. (2008) L-Amino acid oxidase from Naja naja oxiana venom. Comp Biochem Physiol B Biochem Mol Biol 149: 572-580. [Crossref]

72. Samy PR, Gopalakrishnakone P, Bow H, Puspharaj PN, et al. (2010) Identification and characterization of a phospholipase A2 from the venom of the Saw-scaled viper: Novel bactericidal and membrane damaging activities. Biochimie 92: 1854-1866.

73. Xu C, Ma D, Yu H, et al. (2007) A bactericidal homodimeric phospholipases A2 from Bungarus fasciatus venom. Peptides 28: 969-973.

74. Oliveira DG, Toyama MH, Novello JC, Beriam LO Marangoni S (2002) Structura and functional characterization of basic PLA2 isolated from Crotalus durissus terrificus venom. J Protein Chem 21: 161-168.

75. Bhattacharjya S, Ramamoorthy A (2009) Multifunctional host defense peptides functional and mechanistic insights from NMR structures of potent antimicrobial peptides. FEBS J 276: 6465-6473. [Crossref]

76. Ramamoorthy A (2009) Beyond NMR spectra of antimicrobial peptides: dynamical images at atomic resolution and functional insights. Solid State Nucl Magn Reson 35: 201-207. [Crossref]

77. Shai Y (1999) Mechanism of the binding, insertion and destabilization of phospholipid bilayer membranes by alpha-helical antimicrobial and cell non-selective membranelytic peptides. Biochim Biophys Acta 1462: 55-70.

78. Epand RM, Vogel HJ (1999) Diversity of antimicrobial peptides and their mechanisms of action. Biochim Biophys Acta 1462: 11-28.

79. Xia X, Zhang L, Wang Y (2015) The antimicrobial peptide cathelicidin-BF could be a potential therapeutic for Salmonella typhimurium infection. Microbiol Res 171: 45-51.

80. Torres AM, Wong HY, Desai M, Moochhala S, Kuchel PW, et al. (2003) Identification of a novel family of proteins in snake venoms. Purification and structural characterization of nawaprin Nunes. B Biochem Mol 159: 57-63.

81. Rádis-Baptista G, Moreno FB, de Lima Nogueira L, Martins AM, de Oliveira Toyama D, et al. (2006) Crotacetin, a novel snake venom C-type lectin homolog of convulxin, exhibits an unpredictable antimicrobial activity. Cell Biochem Biophys 44: 412-423. [Crossref]

82. Fox JW, Serrano SM (2005) Structural considerations of the snake venom metalloproteinases, key members of the M12 reprolysin family of metalloproteinases. Toxicon 45: 969-985 [Crossref]

Copyright: (C2019 Alam MI. This is an open-access article distributed under the terms of the Creative Commons Attribution License, which permits unrestricted use, distribution, and reproduction in any medium, provided the original author and source are credited. 